"5. State the difference between an observation and an opiuion and give example of each. How does this distinction affect the conduct of the nurse?

" 6. What effect lias hemorrhage in the mother upon the oxygen supply of the unborn child?

" 7 . What fool should be given to a case of gastro-enteritis, and why?

" 8. How does the relatively sniall size of the child affect the care of it as to heat and cold?

"9. What are mucous patches? Where do you find then? What do they look like? Are they contagious?

"10. Give one good rule for determining the 'initial dose' in children."

We believe, therefore, that a nurse who is a graduatc of the Boston Floating Hospital will be familiar with the peculiar anatomical and physiological features of children, the points to be observed in evcry case, and those to be scen only in surgical, contagious, or defectivc children, or in those having somc special forms of discase. She will know what foods arc suitable for various ages and for different discases, and how to prepare them, and the main lines of treatment cmployed, as well as solucthing of the rcasons therefor. She will have lcarned from experience how to irrigate the colon, to wash out the stomach, to give nasal feeding, to get encmata rctained, to give normal salinc solution under the skin, how the pulse and temperaturc run in critical eases, and the modification wlich may be sccured by prompt stimulation. She will be conversant with the important things to be notcd in infants' dejecta and know what arc the peculiarities following certain lines of food. She will have secn, too, the spccimens of discased tissuc of babies over whom she has patiently worked and know why the efforts failed. Such a nursc will be invaluable to a doctor who has a very sick baby under his care. Hc knows that his orders will be skilfully carricd out, that the observations he desires will be made and recorded, and that emergencies will be promptly met.

178 Devonsmine Street, Boston, Mass.

\title{
IS THE PROFESSION BECOMING OVERCROWDED?
}

\section{BY AN OBSERVER}

This question came up before my mind not long ago as I sat with a group of women all of whom had graduated from one of our most thorough-going and excellent schools of nursing. They were five in number: one only was beyond what might be called the best years of a working woman, the rest were cnjoying the prime of vigor.

All were women of notable and exceptional suecess as nurses. They all had in a marked degree that quality of womanliness which comes first 
and foremost among the eharaeteristies of a good nurse. They were sensible, kindly; home-makers, and endowed with sympathy, brains, and tact. I had seen them with patients on private duty and as head nurses of wards.

It seemed a little sad to look at these women and realize that the profession of nursing had lost them,--for they had all entered different lines of work, in which, true enongli. their nurses' training stood them in execllent stead, but in whieh it was not the inain thing.

Two had studied medicine, and each was established in a cosey and lome-like little flat, a sort of combination of the "baclelor-girl" and business woman's apartment, and these two young doctors have already a good general practice, are members of the medieal soeieties. and are doing well finaneially. They are full of interest in social problems, are ready to assist in reform work, and are still also interested in the progress of the nursing profession, although as time goes on this must inevitably beeome overgrown with the affairs of their own medieal eolleagues.

Another had given up nursing for the specialty of massage, and was also suceessful and liappy. Still another had beeome interested in the lives of wage-earning women in offiees and shops. She had done every kind of nursing with sueess, and finally gave up distriet nursing to establish a elub where meals of good quality and small price were served to working-women. Her assistant was also a nurse, and this business enterprise is being eondueted with eminent skill and suceess. The fifth had retired from active nursing from reasons of health and harl worked up for herself a well-paying industry in making surgical supplies, sanitary articles, and outfits, whieh she disposed of in trade channels.

As I contemplated these ex-nurses I eoneluded that there was no immediate danger of the profession being overerowded, and only felt sorry that five ineompetents eould not have been remored to other sphere: instead of these, all so eapable and excellent.

One of them said to me: "Fvery nurse shonld be aldvised to so eultivate and prepare leerself that there shall be at least one other thing in which she may excel, so that she may, if neessary, lave some other way of supporting herself. No nurse should be dependent on nursing alone; she should have some otller resouree in ease her health fails, or her family elaims her, or for any reason she wishes to give up nursing." This seems like sound adviee, and I am inelined to think that if all trained nurses who have taken up other lines of work were to inake themselves known to the Journal, the sum total would be quite astonishing.

Many women, after a period of service in nursing for ten years or so, feeling a louging for lealthy, well people, for vital, ereatire work, go into other aetivities, and I believe this is a good thing for them- 
selves and for the whole service. A eontinual fresh element is thus kept pouring into the work of self-denial and seelusion with the sick, and the fagged and weary ones are dispersing themselves into the strong currents of the world life, there to be reinvigorated and refreshed.

\section{POST-GRADUATE WORK *}

\section{BY LUCY WALKER}

Superintendent of Nurses, Pennsylvania Hospital, Philadelphia; President Philadelphia County Graduate Nurses' Association

We hope to gain to-day some ideas which may be useful in helping us to arrive at more definite eonelusions regarding:

1. The value of post-graduate work.

2. The diffeulties in the way of making it feasible.

3. The best way of obtaining it.

That it is a need we shall all probably agree. Nursing is a very young profession, and has within a very short period of time grown and developed rapidly. Nurses who graduated some years ago were not offered the opportunities of the nurses of to-day. Great changes have taken place in the attitude of hospitals towards their training-sehools. Arrangements have been made for better instruetion and more eareful supervisicn, and a higher order of work is expeeted from the students. In the early days of nursing reform physieinns and surgeons did not require from nurses what to-day they expeet as a matter of eourse. Nurses who lave reently graduated are often given the preference over those whose serviees, by reason of their greater experience, should be of much more value, and as a result the latter fall behind in the race. This is not as it should be. We do not find it so in the medieal profession. Young doetors are eontent after several years of study to wait for suceess, beeause they know that the publie prefers men of experienee. $\Lambda$ nd yet medieine and surgery are also progressing. Why do not the older men, who have not had the opportunities of the younger, also fall behind in the race?

The answer to this question will help us to realize that post-graduate work is of the very highest value. The suceessful young medieal student, after gaining his theoretical knowledge at a college, enters a hospital and gives his services for a term of two years or more in order to gain a practical knowledge of his work. He then opens an offiee, hangs out his sign, and hopes for patients. But does he eonsider his medical education

* Read before the Philadelphia Comity Graduate Nurses' Association. 